University of Nebraska - Lincoln

DigitalCommons@University of Nebraska - Lincoln

\title{
Chlorella Virus Marburg Topoisomerase II: High DNA Cleavage Activity as a Characteristic of Chlorella Virus Type II Enzymes
}

Jennifer S. Dickey

Vanderbilt University School of Medicine

Tae-Jin Choi

Pukyong National University, choitj@pknu.ac.kr

James L. Van Etten

University of Nebraska-Lincoln, jvanetten1@unl.edu

Neil Osheroff

Vanderbilt University School of Medicine, neil.osheroff@vanderbilt.edu

Follow this and additional works at: https://digitalcommons.unl.edu/plantpathpapers

Part of the Other Plant Sciences Commons, Plant Biology Commons, and the Plant Pathology

Commons

Dickey, Jennifer S.; Choi, Tae-Jin; Van Etten, James L.; and Osheroff, Neil, "Chlorella Virus Marburg Topoisomerase II: High DNA Cleavage Activity as a Characteristic of Chlorella Virus Type II Enzymes" (2005). Papers in Plant Pathology. 618.

https://digitalcommons.unl.edu/plantpathpapers/618

This Article is brought to you for free and open access by the Plant Pathology Department at DigitalCommons@University of Nebraska - Lincoln. It has been accepted for inclusion in Papers in Plant Pathology by an authorized administrator of DigitalCommons@University of Nebraska - Lincoln. 


\title{
Chlorella Virus Marburg Topoisomerase II: High DNA Cleavage Activity as a Characteristic of Chlorella Virus Type II Enzymes
}

\author{
Jennifer S. Dickey, ${ }^{1}$ Tae-Jin Choi, ${ }^{2,3}$ \\ James L. Van Etten, ${ }^{2,4}$ and Neil Osheroff ${ }^{1,5}$
}

1 Department of Biochemistry, Vanderbilt University School of Medicine

2 Department of Plant Pathology, University of Nebraska-Lincoln

3 Department of Microbiology, Pukyong National University, Busan 608-737, Korea

4 Nebraska Center for Virology, University of Nebraska-Lincoln

5 Department of Medicine (Hematology/Oncology), Vanderbilt University School of Medicine

Corresponding author - N. Osheroff, tel (615) 322- 4338; fax (615) 343-1166;

email neil.osheroff@vanderbilt.edu

\begin{abstract}
Although the formation of a covalent enzyme-cleaved DNA complex is a prerequisite for the essential functions of topoisomerase II, this reaction intermediate has the potential to destabilize the genome. Consequently, all known eukaryotic type II enzymes maintain this complex at a low steady-state level. Recently, however, a novel topoisomerase II was discovered in Paramecium bursaria chlorella virus-1 (PBCV-1) that has an exceptionally high DNA cleavage activity [Fortune et al. (2001) J. Biol. Chem. 276, 24401-24408]. If robust DNA cleavage is critical to the physiological functions of chlorella virus topoisomerase II, then this remarkable characteristic should be conserved
\end{abstract}

Published in Biochemistry 44 (2005), pp 3899-3908.

DOI: $10.1021 /$ bi047777f

PMID: 15751965

Copyright (C) 2005 American Chemical Society. Used by permission.

Submitted October 18, 2004; revised December 16, 2004; published 18 February 2005.

This work was supported by Grants GM33944 (to N.O.) and GM32441 (to J.L.V.E.) from the National Institutes of Health and Grant P20-RR15635 from the COBRE program of the National Center for Research Resources (to J.L.V.E.). J.S.D. was a trainee under Grant 5 T32 HD07043 from the National Institutes of Health. 
throughout the viral family. Therefore, topoisomerase II from Chlorella virus Marburg-1 (CVM-1), a distant family member, was expressed in yeast, isolated, and characterized. CVM-1 topoisomerase II is 1058 amino acids in length, making it the smallest known type II enzyme. The viral topoisomerase II displayed a high DNA strand passage activity and a DNA cleavage activity that was $\sim 50$-fold greater than that of human topoisomerase II $\alpha$. High DNA cleavage appeared to result from a greater rate of scission rather than promiscuous DNA site utilization, inordinately tight DNA binding, or diminished religation rates. Despite the fact that CVM-1 and PBCV-1 topoisomerase II share $\sim 67 \%$ amino acid sequence identity, the two enzymes displayed clear differences in their DNA cleavage specificity/site utilization. These findings suggest that robust DNA cleavage is intrinsic to the viral enzyme and imply that chlorella virus topoisomerase II plays a physiological role beyond the control of DNA topology.

The topological state of the genetic material profoundly influences a number of critical nuclear processes including DNA replication, transcription, recombination, and mitosis $(1,2)$. For example, while global underwinding of DNA dramatically increases rates of replication, overwinding of the double helix ahead of DNA tracking systems presents a formidable obstacle to replication fork progression and transcription (1-5). Furthermore, DNA knots and tangles that accumulate as a result of recombination and replication must be resolved for the two strands of the double helix to separate or for chromosomes to segregate during mitosis $(1-4,6)$.

In all living systems, levels of DNA under- and overwinding, knotting, and tangling are controlled by ubiquitous enzymes known as topoisomerases $(1,4,7-10)$. Type II topoisomerases play critical roles in virtually every aspect of DNA metabolism. Although lower eukaryotes such as yeast and Drosophila express only a single form of topoisomerase II $(11,12)$, vertebrates require two closely related isoforms of the enzyme, topoisomerase II $\alpha$ and $\operatorname{II} \beta(13,14)$. Topoisomerase II $\alpha$ is present at low concentrations in quiescent cells but increases dramatically during periods of cell proliferation $(4,15-19)$. Therefore, it is believed that this isoform plays fundamental roles in DNA replication and mitotic events such as chromosome segregation. In contrast, cellular levels of topoisomerase II $\beta$ appear to be independent of proliferative status $(4,15,20,21)$. Although the precise physiological functions of topoisomerase II $\beta$ have yet to be defined, it is believed that this isoform is involved in a variety of ongoing nuclear processes.

Type II topoisomerases control the topological state of DNA by passing an intact double helix through a transient double-stranded break that 
they generate in a separate segment of the genetic material. To regulate the opening and closing of the "DNA gate" during this process, topoisomerase II forms covalent bonds between its active site tyrosyl residues and the newly generated DNA termini. These covalent enzyme-DNA complexes are known as cleavage complexes $(1,4,7,8,10,22)$.

Type II topoisomerases are essential to the survival of all proliferating cells. However, because these enzymes generate double-stranded DNA breaks as a mandatory prerequisite for the strand passage event, they pose a threat to genomic integrity every time they function $(10,23$, 24). Under normal circumstances, topoisomerase II opens and closes the DNA gate very rapidly. Thus, at any given moment, topoisomerase IIDNA cleavage complexes are present at low levels and are tolerated by the cell. However, physiological conditions that increase either the lifetime or the concentration of cleavage complexes convert topoisomerase II from an essential enzyme to a potent cellular toxin that fragments the genetic material (25-29).

Because the DNA cleavage activity of topoisomerase II has the potential to destabilize the genome, the enzyme plays a central role in cancer. While several widely used anticancer drugs act by increasing levels of enzyme-mediated DNA scission, evidence suggests that the actions of topoisomerase II may trigger the chromosomal breaks that initiate specific types of leukemia $(26,27,30-43)$. The difference between killing malignant cells and initiating cancer probably is related to the physiological levels of enzyme-induced DNA strand breaks. If the numbers of DNA breaks are sufficiently high, cells become overwhelmed and induce apoptotic or other death pathways. Conversely, if the numbers of breaks are sublethal, they trigger recombination/repair pathways that under some circumstances generate cancer-causing chromosomal translocations.

Due to the potentially lethal nature of the topoisomerase II-mediated DNA scission reaction, low levels of DNA cleavage are characteristic of all known eukaryotic type II enzymes $(1,4,7,8,10,22)$. Consequently, this feature was believed to be a hallmark of this enzyme class. Recently, however, a novel type II topoisomerase was discovered that possesses a dramatically (30-50-fold) higher DNA cleavage activity. The enzyme is encoded by Paramecium bursaria chlorella virus-1 $(\mathrm{PBCV}-1)^{1}$ (44-47). PBCV-1 topoisomerase II is significantly smaller than

1. Abbreviations: PBCV-1, Paramecium bursaria chlorella virus-1; CVM-1, Chlorella virus Marburg-1; PCR, polymerase chain reaction; kDNA, kinetoplast DNA. 
its eukaryotic counterpart due to a large C-terminal deletion, but otherwise displays high amino acid sequence identity. Furthermore, aside from a robust DNA cleavage activity, the catalytic reaction of the viral enzyme is in all respects typical of eukaryotic type II topoisomerases.

It is not known what role topoisomerase II plays in the life cycle of chlorella viruses. The extremely high DNA scission activity of PBCV-1 topoisomerase II suggests that the viral enzyme may play alternative roles beyond the normal control of DNA topology, such as initiating genetic recombination in the virus or death pathways in the host cell. If robust DNA cleavage is critical to the physiological functions of chlorella virus topoisomerase II, then this remarkable characteristic should be evolutionarily maintained throughout this diverse and ancient group of viruses (48-51). Therefore, recombinant topoisomerase II from Chlorella virus Marburg-1 (CVM-1), a distantly related family member (52), was expressed in yeast, isolated, and characterized. CVM-1 topoisomerase II displayed a DNA cleavage activity that was even higher than that seen for the PBCV-1 enzyme. This finding strongly suggests that the high DNA cleavage activity of the chlorella virus type II topoisomerases is intrinsic to this viral enzyme family and implies that it provides an important physiological benefit for the virus.

\section{Experimental Procedures}

Enzymes and Materials.

Negatively supercoiled pBR322 DNA was prepared using a Plasmid Mega Kit (Qiagen) as described by the manufacturer. Kinetoplast DNA (kDNA) was isolated from Crithidia fasciculata as described by Englund et al. (53). [ $\left.\gamma^{-32} \mathrm{P}\right]$ ATP ( $\left.5000 \mathrm{Ci} / \mathrm{mmol}\right)$ was obtained from ICN. Etoposide was from Sigma, amsacrine was from Bristol-Myers Squibb, and CP115,953 was from Pfizer. These drugs were stored at $4{ }^{\circ} \mathrm{C}$ as 10 or 20 mM stock solutions in 100\% DMSO. The pPM231 vector used for expression of viral type II topoisomerases was the gift of Dr. Louise Prakash. All other chemicals were analytical reagent grade.

Cloning of the CVM-1 Topoisomerase II Gene.

The putative topoisomerase II ORF of 3174 base pairs was amplified from CVM-1 genomic DNA by the polymerase chain reaction (PCR) with KOD Hot Start DNA polymerase (Novagen). The following sequences 
were used for the forward and reverse primers, respectively: TACTAACGGATCCAATAAACATGGC and TATGTTTAGGATCCAATTTCAAATG. CVM-1 genomic DNA was denatured at $94{ }^{\circ} \mathrm{C}$ for $2 \mathrm{~min}$ and subjected to $40 \mathrm{cy}$ cles of PCR using the following program: denaturation at $94{ }^{\circ} \mathrm{C}$ for $15 \mathrm{~s}$, annealing at $50{ }^{\circ} \mathrm{C}$ for $30 \mathrm{~s}$, and primer extension for $4 \mathrm{~min}$ at $68^{\circ} \mathrm{C}$. Following PCR, primers were allowed to extend for an additional $10 \mathrm{~min}$ at $68{ }^{\circ} \mathrm{C}$, and the final product was purified by gel electrophoresis. The pMP231 vector was digested with BglII and treated with calf intestinal phosphatase for $1 \mathrm{~h}$. The PCR product was digested with BamHI, ligated into the vector, and transformed into Escherichia coli TOP10. The CVM-1 topoisomerase II construct was sequenced to confirm the primary structure of the gene. The resultant plasmid, pPMTOP030, was transformed into Saccharomyces cerevisiae JEL-1 1 top 1 by heat shock. The GenBank accession number for CVM-1 topoisomerase II is AY761524.

Expression and Purification of Recombinant Type II Topoisomerases.

CVM-1 topoisomerase II and PBCV-1 topoisomerase II were expressed in $S$. cerevisiae JEL-1 1 top 1 and purified by a modification of the procedure of Lavrukhin et al. (44). A detailed protocol for the purification of CVM-1 topoisomerase II is presented in the Supporting Information that accompanies this paper. Human topoisomerase II $\alpha$ was expressed and purified as described by Kingma et al. (54).

\section{DNA Relaxation.}

DNA relaxation reactions were carried out as described by Fortune and Osheroff (55). Assay mixtures contained 0.05-4 nM CVM-1 topoisomerase II, PBCV-1 topoisomerase II, or human topoisomerase II $\alpha, 1 \mathrm{mM}$ ATP, and $5 \mathrm{nM}$ negatively supercoiled pBR322 DNA in a total of $20 \mu \mathrm{L}$ of DNA relaxation buffer (CVM-1 topoisomerase II and PBCV-1 topoisomerase II, 10 mM Tris-HCl, pH 8.5, $62.5 \mathrm{mM} \mathrm{NaCl}, 62.5 \mathrm{mM} \mathrm{KCl}, 0.1 \mathrm{mM}$ NaEDTA, $2.5 \mathrm{mM} \mathrm{MgCl}_{2}$, and 2.5\% glycerol; human topoisomerase II $\alpha$, $10 \mathrm{mM}$ Tris-HCl, pH 7.9, $175 \mathrm{mM} \mathrm{KCl,} 5 \mathrm{mM} \mathrm{MgCl}_{2}, 0.1 \mathrm{mM}$ NaEDTA, and $2.5 \%$ glycerol). Reactions were incubated at $30{ }^{\circ} \mathrm{C}(\mathrm{CVM}-1), 25^{\circ} \mathrm{C}$ (PBCV1 ), or $37^{\circ} \mathrm{C}$ (human) for $15 \mathrm{~min}$ and stopped by the addition of $3 \mu \mathrm{L}$ of stop solution ( $0.5 \%$ SDS, $77 \mathrm{mM}$ EDTA). Proteinase $\mathrm{K}$ was added $(2 \mu \mathrm{L}$ of a $0.8 \mathrm{mg} / \mathrm{mL}$ solution), and reactions were incubated for $30 \mathrm{~min}$ at 45 ${ }^{\circ} \mathrm{C}$ to digest the enzyme. Samples were mixed with agarose gel loading buffer (60\% sucrose in $10 \mathrm{mM}$ Tris- $\mathrm{HCl}, \mathrm{pH} 7.9)$ and subjected to electrophoresis in 1\% agarose gels in $100 \mathrm{mM}$ Tris-borate, $\mathrm{pH}$ 8.3, 2 mM 
EDTA. Gels were stained for 30 min with $0.5 \mu \mathrm{g} / \mathrm{mL}$ ethidium bromide, and DNA bands were visualized by UV light and were quantified using an Alpha Innotech digital imaging system (San Leandro, CA).

\section{Decatenation of Kinetoplast DNA ( $k D N A)$.}

DNA decatenation reactions were carried out as described by Miller et al. (56). Assay mixtures contained $1 \mathrm{mM}$ ATP, $5 \mathrm{nM}$ kDNA, and 0-20 nM topoisomerase II in a total of $20 \mu \mathrm{L}$ of DNA relaxation buffer. Decatenation was initiated by the addition of topoisomerase II, followed by incubation for $30 \mathrm{~min}$ at $30^{\circ} \mathrm{C}(\mathrm{CVM}-1), 25^{\circ} \mathrm{C}(\mathrm{PBCV}-1)$, or $37^{\circ} \mathrm{C}$ (human). Reactions were terminated by the addition of $3 \mu \mathrm{L}$ of stop solution. Samples were processed and products were quantified as in the preceding section.

\section{DNA Cleavage.}

Plasmid DNA cleavage reactions were based on the procedure of Fortune and Osheroff (55). Unless stated otherwise, reaction mixtures contained $10 \mathrm{nM}$ negatively supercoiled pBR322 DNA in a total of $20 \mu \mathrm{L}$ of DNA cleavage buffer (CVM-1 topoisomerase II, $10 \mathrm{mM}$ Tris- $\mathrm{HCl}$, $\mathrm{pH}$ 8.5, $120 \mathrm{mM} \mathrm{KCl}, 0.1 \mathrm{mM} \mathrm{NaEDTA}, 15 \mathrm{mM} \mathrm{MgCl}_{2}$, and 2.5\% glycerol; PBCV-1 topoisomerase II, $10 \mathrm{mM}$ Tris- $\mathrm{HCl}, \mathrm{pH} 8.5,62.5 \mathrm{mM} \mathrm{NaCl}, 62.5 \mathrm{mM} \mathrm{KCl}$, $0.1 \mathrm{mM} \mathrm{NaEDTA}$, $2.5 \mathrm{mM} \mathrm{MgCl}_{2}$, and 2.5\% glycerol; human topoisomerase II $\alpha, 10 \mathrm{mM}$ Tris- $\mathrm{HCl}, \mathrm{pH}$ 7.9, $100 \mathrm{mM} \mathrm{KCl}, 5 \mathrm{mM} \mathrm{MgCl}{ }_{2}, 0.1 \mathrm{mM}$ NaEDTA, and $2.5 \%$ glycerol). In reactions that optimized DNA cleavage by CVM- 1 topoisomerase II, the $\mathrm{pH}, \mathrm{MgCl}_{2}$ concentration, reaction temperature, or $\mathrm{KCl}$ concentration was varied. DNA cleavage was initiated by the addition of topoisomerase II (final enzyme concentrations were $20 \mathrm{nM}$ for CVM-1 and PBCV-1 and $200 \mathrm{nM}$ for human unless stated otherwise). Reaction mixtures were incubated for $6 \mathrm{~min}$ at $30^{\circ} \mathrm{C}$ (CVM-1), $25^{\circ} \mathrm{C}$ (PBCV-1), or $37^{\circ} \mathrm{C}$ (human) to establish cleavage/religation equilibria. Cleavage intermediates were trapped by the addition of $2 \mu \mathrm{L}$ of 1.15\% SDS and $2 \mu \mathrm{L}$ of $115 \mathrm{mM}$ NaEDTA, pH 8.0 (CVM-1 and PBCV-1), or $2 \mu \mathrm{L}$ of $5 \%$ SDS and $2 \mu \mathrm{L}$ of $250 \mathrm{mM}$ NaEDTA, pH 8.0 (human). Proteinase $\mathrm{K}$ was added ( $2 \mu \mathrm{L}$ of $0.8 \mathrm{mg} / \mathrm{mL}$ ), and mixtures were incubated for $30 \mathrm{~min}$ at $45^{\circ} \mathrm{C}$ to digest the type II enzyme. Samples were mixed with $2 \mu \mathrm{L}$ of agarose gel loading buffer, heated for $2 \mathrm{~min}$ at $45^{\circ} \mathrm{C}$, and subjected to electrophoresis in $1 \%$ agarose gels in $40 \mathrm{mM}$ Tris-acetate, $\mathrm{pH}$ 8.3, $2 \mathrm{mM}$ EDTA containing $0.5 \mu \mathrm{g} / \mathrm{mL}$ ethidium bromide. DNA cleavage 
was monitored by the conversion of negatively supercoiled plasmid to linear molecules. DNA bands were quantified by digital imaging as described above. To determine whether DNA cleavage mediated by CVM-1 topoisomerase II was reversible, EDTA $10 \mathrm{mM}$ final concentration, in lieu of post-SDS addition) was added prior to treatment with SDS. To determine whether cleavage was protein-linked, proteinase $\mathrm{K}$ treatment was omitted.

DNA sites cleaved by CVM-1 topoisomerase II, PBCV-1 topoisomerase II, or human topoisomerase II $\alpha$ were mapped as described by O'Reilly and Kreuzer (57). A linear 4330 bp fragment (HindIII/EcoRI) of pBR322 plasmid DNA singly labeled with [32P]phosphate on the $5^{\prime}$-terminus of the HindIII site was used as the cleavage substrate. Reaction mixtures contained $0.35 \mathrm{nM}$ DNA molecules and $60 \mathrm{nM}$ topoisomerase II in $50 \mu \mathrm{L}$ of cleavage buffer. Assays were carried out in the absence of compound or in the presence of $50 \mu \mathrm{M}$ etoposide, amsacrine, or CP-115,953. Reactions were started by the addition of the enzyme, and the mixtures were incubated for $10 \mathrm{~min}$ at $30{ }^{\circ} \mathrm{C}(\mathrm{CVM}-1), 25^{\circ} \mathrm{C}(\mathrm{PBCV}-1)$, or $37^{\circ} \mathrm{C}$ (human). Cleavage intermediates were trapped by adding $5 \mu \mathrm{L}$ of $1.15 \%$ SDS followed by $5 \mu \mathrm{L}$ of $115 \mathrm{mM}$ NaEDTA (CVM-1 and PBCV-1), or $5 \mu \mathrm{L}$ of $10 \%$ SDS followed by $5 \mu \mathrm{L}$ of $250 \mathrm{mM}$ NaEDTA, pH 8.0 (human), and the enzymes were digested with proteinase $\mathrm{K}$ ( $5 \mu \mathrm{L}$ of a $0.8 \mathrm{mg} / \mathrm{mL}$ solution) for $30 \mathrm{~min}$ at $45^{\circ} \mathrm{C}$. Products were precipitated twice in $100 \%$ ethanol, dried, resuspended in 40\% formamide, $8.4 \mathrm{mM}$ EDTA, $0.02 \%$ bromophenol blue, and $0.02 \%$ xylene cyanole FF, and subjected to electrophoresis in $6 \%$ acrylamide gels. Gels were fixed in $10 \%$ methanol/10\% acetic acid for $5 \mathrm{~min}$ and dried. DNA cleavage products were visualized on a Bio-Rad Molecular Imager FX.

\section{Topoisomerase II-DNA Binding.}

Topoisomerase II-DNA binding was assessed using a nitrocellulose filterbinding assay. Linear pBR322 DNA radiolabeled with [32P]phosphate was prepared as described in the DNA Cleavage section. Binding mixtures contained $5 \mathrm{nM}$ DNA and 10-400 nM topoisomerase II in a total of $20 \mu \mathrm{L}$ of DNA binding buffer [10 mM Tris-HCl (CVM-1 topoisomerase II, pH 8.5; human topoisomerase II $\alpha$, pH 7.9), $5 \mathrm{mM} \mathrm{KCl,} 0.1 \mathrm{mM}$ NaEDTA, and 2.5\% glycerol] and were incubated for $6 \mathrm{~min}$ at $30^{\circ} \mathrm{C}(\mathrm{CVM}-1)$ or $37^{\circ} \mathrm{C}$ (human). Nitrocellulose membranes ( $0.45 \mu \mathrm{m}$ HA, Millipore) were prepared by incubation in DNA binding buffer for $10 \mathrm{~min}$. Samples were applied 
to the membranes and filtered in vacuo. Membranes were washed three times with $1 \mathrm{~mL}$ of DNA binding buffer, dried, and submerged in $8 \mathrm{~mL}$ of scintillation fluid (Econo-Safe, Research Products International). Radioactivity remaining on the membranes was quantified using a Beckman LS 5000 TD scintillation counter. The percent DNA bound to topoisomerase II was determined by the ratio of the radioactivity on the membranes vs that of the input DNA.

\section{DNA Religation.}

Topoisomerase II DNA religation was monitored according to the procedure of Robinson and Osheroff (58). Topoisomerase II DNA cleavage/religation equilibria were established as above for plasmid DNA cleavage. Religation was initiated by shifting reactions from $30^{\circ} \mathrm{C}(\mathrm{CVM}-1)$ or 37 ${ }^{\circ} \mathrm{C}$ (human) to $-5^{\circ} \mathrm{C}$. Reactions were stopped at time points following the temperature shift by the addition of $2 \mu \mathrm{L}$ of $1.15 \%$ SDS followed by $2 \mu \mathrm{L}$ of $115 \mathrm{mM}$ NaEDTA, pH 8.0 (CVM-1), or $2 \mu \mathrm{L}$ of 5\% SDS followed by $2 \mu \mathrm{L}$ of $250 \mathrm{mM}$ NaEDTA, pH 8.0 (human). Samples were processed and analyzed as described for topoisomerase II plasmid DNA cleavage reactions. Religation was monitored by quantifying the loss of linear DNA.

\section{Results}

Because of the potentially mutagenic and lethal effects of topoisomerase II-generated DNA breaks, the enzyme maintains low levels of covalent DNA cleavage complexes throughout its strand passage event (1, $10,23)$. This characteristic is an invariant feature of all known eukaryotic type II enzymes. Therefore, it was remarkable when a eukaryoticlike topoisomerase II from chlorella virus PBCV-1 was discovered that displayed a DNA scission activity $\sim 30$ times higher than that of human topoisomerase II $\alpha$ (44-46). The extraordinary DNA cleavage activity of PBCV-1 topoisomerase II raises questions regarding the physiological role of this enzyme.

If robust DNA cleavage is critical to the in vivo functions of chlorella virus topoisomerase II, then this remarkable characteristic should be maintained throughout the viral family (48-51). Therefore, topoisomerase II from a distantly related chlorella virus, CVM-1, was characterized. The two viral strains differ in a number of critical aspects. CVM-1 and PBCV-1 infect different Chlorella species, Pbi and NC64A, respectively, 
and will not attach to the other's algal host $(49,52)$. In addition, the methylation states of CVM-1 and PBCV-1 DNA differ markedly. For example, while $41.9 \%$ of the cytosines in the CVM-1 genome exist as 5-methylcytosine, only $1.9 \%$ are modified in PBCV-1 $(51,59)$. Finally, as determined by dot blot analysis, the topoisomerase II genes in these two viral strains display little cross-reactivity (45). Since CVM-1 and PBCV-1 display considerable divergence, similarities between the type II topoisomerases of these two viruses would imply a strong conservation over the course of chlorella virus evolution.

Cloning, Expression, and Purification of CVM-1 Topoisomerase II.

Random sequencing of the CVM-1 genome identified an open reading frame that was predicted to encode a protein with $67 \%$ amino acid sequence identity to PBCV-1 topoisomerase II (Figure 1). The putative CVM-1 topoisomerase II is 1058 amino acids in length as compared to 1531 for human topoisomerase II $\alpha$. The major difference between the two enzymes is that CVM-1 lacks the variable C-terminal domain of eukaryotic topoisomerase II. The amino acid sequence of CVM-1 topoisomerase II is $43 \%$ identical to the first 1058 residues of human topoisomerase II $\alpha$ (Figure 1). Finally, CVM-1 topoisomerase II is three amino acid residues shorter than the PBCV-1 enzyme, making it the smallest known type II enzyme.

The predicted CVM-1 topoisomerase II gene was amplified by PCR and cloned into the galactose-inducible pMP231 expression plasmid to create pPMTOP030. S. cerevisiae JEL-1 top1 was transformed with pPMTOP030, and CVM-1 topoisomerase II was expressed and purified to greater than $95 \%$ homogeneity by a procedure similar to that used to isolate the PBCV-1 type II enzyme (see Supporting Information Figure S1). The electrophoretic mobility of CVM-1 topoisomerase II on denaturing polyacrylamide gels was consistent with the predicted molecular mass of $120 \mathrm{kDa}$.

Catalytic Activity of CVM-1 Topoisomerase II.

To determine whether the CVM-1 protein was a type II topoisomerase, its ability to catalyze double-stranded DNA passage was determined. First, the relaxation of negatively supercoiled plasmid molecules was assessed (Figure 2). The recombinant CVM-1 protein displayed a vigorous DNA relaxation activity that was at least 10 -fold higher than that of human topoisomerase II $\alpha$ and slightly higher than that of PBCV-1 


\begin{abstract}
CVM-1 -1 PBCV 1 -
human MEVSPLQPVNENMQVNKIKKNEDAKKRLSVERIYQKKTQLEHILLRPDTYIGSVELVTQQMWVYDEDVGINYREVTFVPGLYKIFDEILVNAADNKQRDPKMSCIRVTIDPENNLISIWN 120

CVM-1 DGCSISLEKND-EGIYIPEMIFGHLLSGENFDDTEERTGAGRNGYGSKLTNIFSKIFSVEIYDGSHK--YVQSWSDNMISVSKAKITKSSKAPSITTSFVPDLARFGMTDIDDDTRSILV 205 PBCV-1 DGCNIPIEKHDVEKCYIPELIFGHLLAGENFDDTEQRTGAGRNGIGSKATNIF SKKFDVEICDGKKK--YKQSWENNMSVMSKPKVTTCSKDSYITTTFFPDPERFGIDSFDDDTMS IMV 205 human NGKGIPVVEHKVEKMYVPALIFGQLLTSSNYDDDEKKVTGGRNGYGAKLCNIFSTKFTVETASREYKKMFKQTWMDNMGRAGEMELKPFNGEDYTCITFQPDLSKFKMQSLDKDIVALMV 240

CVM-1 RRVYDMAAVLGSVRVFDGKRLEVKTPLDYFKLYT--------DEKVVFBS-ADGWSIGVAPAN-EFACVSFVNASAAR-GGTHVDAVVNSIAKAVVEAASKKK---TIVKPTMVKNKL 310 PBCV-1 RRVYDMAAVLNKVKVMLNGKRLEIKNTEDYFSLYVGNKT-----ETKRAFEHTPENWDVAVSCSD-EFTPVSFVNSVVTR-GGTHVNAVTDAVAKAVVEAAAKKK---IVVKPMTVKGRM 315 human RRAYDIAGSTKDVKVFLNGNKLPVKGFRSYVDMYLKDKLDETGNSLKVIHEQVNHRWEVCLTMSEKGFQQISFVNSIATSKGGRHVDYVADQIVTKLVDVVKKKNKGGVAVKAHQVKNHM 360

CVM-1 FVFVNAKIVNPTFSSQTKDILTSR----NIKFSPSAAFLKKATGLVLDAVIAETNVRESLVDARLLKKTDGVKKTRLTGIKKLTDAAWAGTKNSGLCTLILTEGDSAATLATAGLAVVGR 426 PBCV-1 FVFVNATVVNPTFDSQTKEILTSR----NARVTLSDTFVKKAVGVLLDAVIQETNVRTSLVDQKELKKTDGAKKSRVSGIPKLNDAAWAGTNHSKMCTLILTEGDSAATLAIAGLSVVGR 431 human WIFVNALIENPTFDSQTKENMTLQPKSFGSTCQLSEKFIKAAIGCGIVESILNWVKFKAQVQLN--KKCSAVKHNRIKGIPKLDDANDAGGRNSTECTLILTEGDSAKTLAVSGLGVVGR 478

CVM-1 ERYGIFPLRGKLLNVRDASVSSIAANAEIAAIKQILGLQVGKTYKDAS---SLRYGSVMLMTDADVDGSHISALVMNFFHAQFPSLLAVPGFLKKFSTPIVVASRGKDIKEFYSLPDYES 543 PBCV-1 ERYGVF PLRGKLLNVRDASVASITKNEEITALKQILGLQTGKVYKDTS---SLRYGHVMIMTDADVDGTHISGLVMNFFHSCFPSLLEIPGFLKKFITPIVVAKKGKDVREFYSLPDYED 548 human DKYGVFPLRGKILNVREASHKQIMENAEINNIIKIVGLQYKKNYEDEDSLKTLRYGKIMIMTDQDQDGSHIKGLLINF IHHNWPSLLRHR-FLEEF ITPIVKVSKNKQEMAFYSLPEFEE 597

CVM-1 WKQNTADCAKWSIKYFKGLGTSTSEDAKKYFKNLKSLVKIFGWTE-DSGELIDRSFNKSRPDERKTWLLDFQPGNQ----------LDQSKTNIPVPDFIDKELILFSRYDVERSIPS 650 PBCV-1 WVKTTKDYSKYQIKYYKGLGTSSSTDAKHYFSNLKTLMKTFTWTS-DSGELIDRSFNKTRAEDRKEWMTAYEPGNQ---------LDHKKPEVPVPDFIDKELILFSRYDLERSIPS 655 human WKSSTPNHKKWKVKYYKGLGTSTSKEAKEYFADMKRHRIQFKYSGPEDDAAISLAFSKKQIDDRKEWLTNFMEDRRQRKLLGLPEDYLYGQTTTYLTYNDF INKELILF SNSDNERSIPS 717

CVM-1 VVDGLKPSORKILFAAFKRNLTNEMKVAOFSGYVAEHSGYHHGEOSLOGAIVGMAODYVGSNNMNLLLPNGOFGSRLLGGKDSASARYIFTKLSPATROVFNQSDDVLLKYLBDDGSSIE 770 PBCV-1 VVDGFKPSQRKVLYCAFKRNLTSDVKVAQFSGYVAEHSAYHHGEVSLQGTIVNLAQDYVGSNNINWLLPEGQFGSRLQGGKDHASARYIFTKLNPKTRQVFVDTDDNLLKYLYDDGDKIE 77S human MVDGLKPGQRKVLFTCFKRNDKREVKVAQLAGSVAEMSSYHHGEMSLMETIINLAQNFVGSNNLNLLQPIGQFGTRLHGGKDSASPRYIFTMLSSLARLLFPPKDDHTLKFLYDDNQRVE 837

CVM-1 PEWYVPAIPFLLVNGANGIGTGFSTDIPSYNPKDIIDNVKRLISGKEMVPMTPWYKGFTGTIVQNDNGTFTCKG-VAKVNGKVVVVSELPIGTWTSDYKDFLEGLVEK-------KVIVDF 883 PBCV-1 PECYVPIIPSILVNGSSGIGTGSSTNIPSYNPKDIVDNVKRLISGEDLVEMKPWYKGFKGKIMETSPGVYVTKG-LYMPNGKTIVVSELPVGKWTHDYKEHLDGLLEK------KIISYF 888 human PEWYIPIIPMVLINGAEGIGTGWSCKI PNFDVREIVNNIRRLMDGEEPLPMLPSYKNFKGTIEELAPNQYVISGEVAILNSTTIBISELPVRTWTQTYKEQVLEPMLNGTEKTPPLITDY 957

CVM-1 REKHTEKNVMFEIDYSGE---2---PDISILKLEKVIRTTNMHAFDPQGKIKKYADPLDIIRDWFEVRREFYTKRKNYLLKDLSHKAAIAENKHRFITLIVNDELVLSKKTESVILSEL 995 PBCV-1 REKHSDTDVLFEIDFVGN-------PNIDILKLETTIRSTNMHAFDPSGKIKKYDTPLDIIRDWFEVRKDLYVKRKAYLLEDLTHRTNIAQNKHRFITMVNNDEIIINKKHESVISAEL 1000 human REYHTDTTVKFVVKMTEEKLAEAERVGLHKVFKLQTSLTCNSMVLFDHVGCLKKYDTVLDILRDFFELRLKYYGLRKEWLLGMLGAESAKLNNQARF ILEKIDGKIIIENKPKKELIKVL 1077

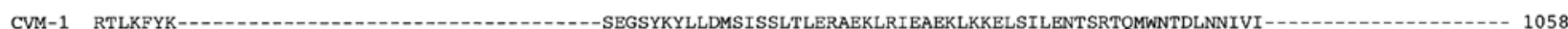
PBCV-1 EKLNFYK--1 human IQRGYDSDPVKAWKEAQQKVPDEEENEESDNEKETEKSDSVTDSGPTFNYLLDMPLWYLTKEKKDELCRLRNEKEQELDTLKRKSPSDLWKEDLATFIEELEAVEAKEKQDEQVGLPGKG 1197

CVM-1 PBCV-1 2 human GKAKGKKTQMAEVLPSPRGQRVIPRITIEMKAEAEKKNKKKIKNENTEGSPQEDGVELEGLKQRLEKKQKREPGTKTKKQTTLAFKPIKKGKKRNPWPDSESDRSSDESNFDVPPRETEP 1317

CVM-1

PBCV-1 -

human LKQRLEKKQKREPGTKTKKQTTLAFKPIKKGKKRNPWPDSESDRSSDESNFDVPPRETEPRRAATKTKFTMDLDSDEDFSDFDEKTDDEDFVPSDASPPKTKTSPKLSNKELKPQKSVVS 1377

CVM-1

PBCV-1 - - -

human DLEADDVKGSVPLSSSPPATHFPDETEITNPVPKKNVTVKKTAAKSQSSTSTTGAKKRAAPKGTKRDPALNSGVSQKPDPAKTKNRRKRKPSTSDDSDSNFEKIVSKAVTSKKSKGESDD 1497

CVM-1

PBCV-1 -

human FHMDFDSAVAPRAKSVRAKKPIKYLEESDEDDLF 1531
\end{abstract}

Figure 1: The amino acid sequences of CVM-1 topoisomerase II (CVM-1), PBCV-1 topoisomerase II (PBCV-1), and human topoisomerase II $\alpha$ (human) were aligned using the ClustalW sequence alignment tool provided by the European Bioinformatics Institute (www.ebi.ac.uk/clustalw). The presumed active site tyrosyl residue of the CVM-1 enzyme is located at position 737. Virtually all of the amino acid residues that are highly conserved among eukaryotic type II topoisomerases also are present in CVM-1 topoisomerase II. However, the viral type II topoisomerase lacks the C-terminal domain typical of eukaryotic type II enzymes.

topoisomerase II. This finding confirms that the CVM-1 protein is a topoisomerase. However, it does not establish whether it is a type I or a type II enzyme. While type I topoisomerases relax plasmids by making transient single-stranded DNA breaks and require no high-energy cofactor (9, 60-65), type II enzymes act by creating double-stranded DNA breaks and require ATP to carry out strand passage $(10,66-68)$. Since the CVM-1 


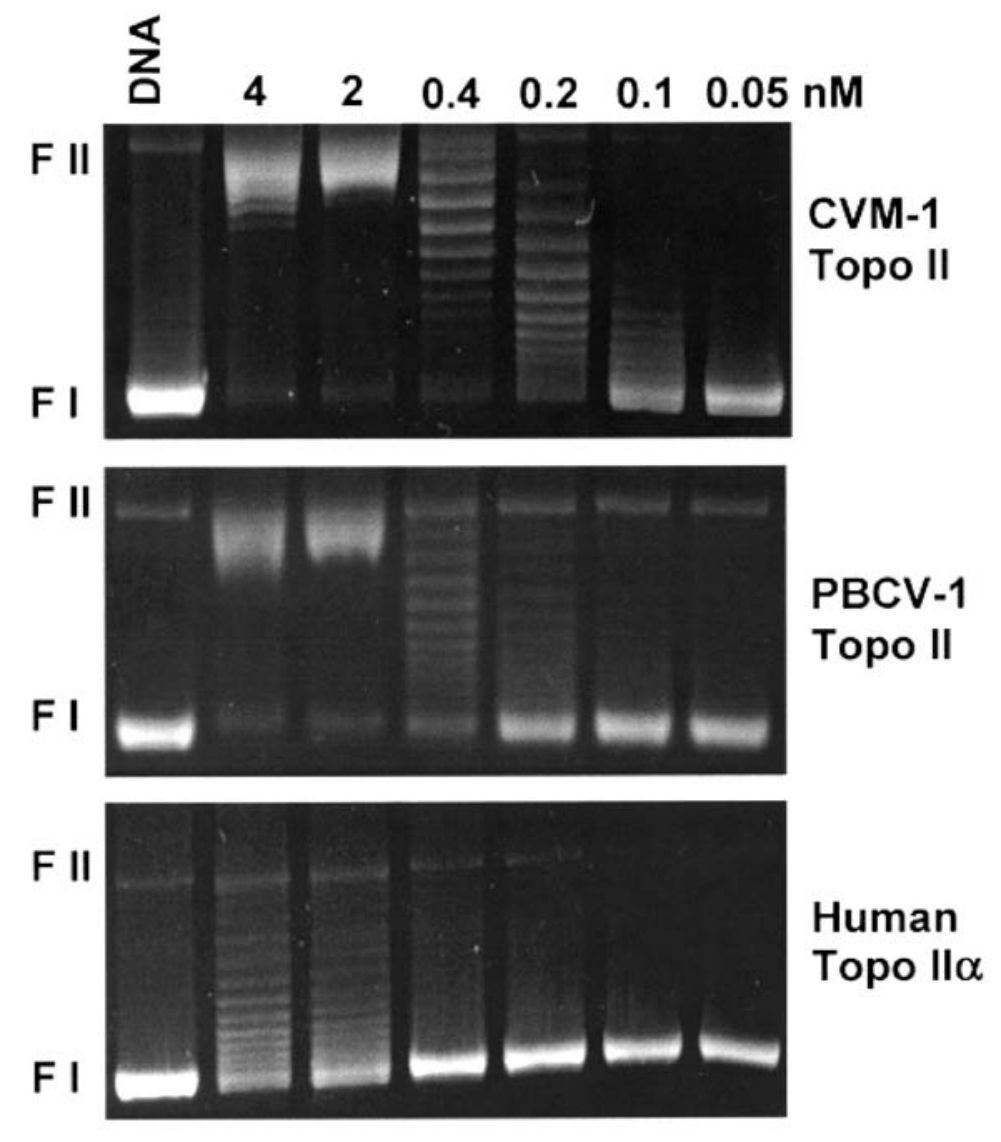

Figure 2: Relaxation of negatively supercoiled pBR322 plasmid DNA by CVM-1 topoisomerase II (top), PBCV-1 topoisomerase II (middle), or human topoisomerase II $\alpha$ (bottom). DNA relaxation reactions were carried out for $15 \mathrm{~min}$ in either the absence of enzyme (DNA) or the presence of 0.05-4 nM enzyme. Ethidium bromide-stained gels that are representative of three independent experiments are shown. Negatively supercoiled DNA (form 1, FI) and nicked circular DNA (form 2, FII) are indicated.

enzyme was unable to relax the plasmid in the absence of ATP, it appears to be a type II topoisomerase (data not shown). To further demonstrate that the enzyme is topoisomerase II, a second assay, DNA decatenation, was utilized. Since uncoupling of double-stranded DNA rings requires a double-stranded DNA passage event, only type II topoisomerases can catalyze this reaction. As seen in Figure 3, CVM-1 topoisomerase II decatenated kDNA at a higher rate than human topoisomerase II $\alpha$ and was as efficient as PBCV-1 topoisomerase II. Furthermore, no decatenation occurred in the absence of ATP. These findings provide strong evidence that the CVM-1 enzyme is indeed topoisomerase II. 


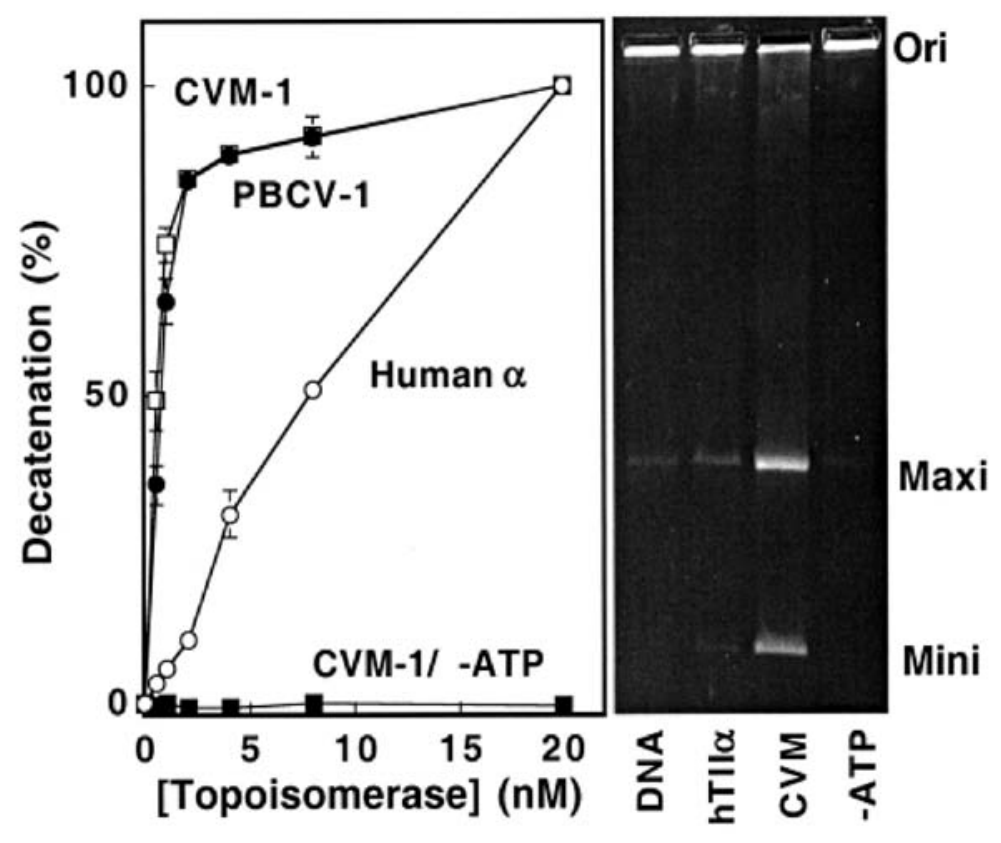

Figure 3: Decatenation of kDNA by CVM-1 topoisomerase II. The percent decatenation was determined by quantifying minicircles that were released from kDNA networks by CVM-1 topoisomerase II in the presence (closed circles) or absence (closed squares) of ATP, by human topoisomerase II $\alpha$ in the presence of ATP (open circles), or by PBCV-1 topoisomerase II in the presence of ATP (open squares) and is shown on the left. Error bars represent the standard deviation of three independent experiments. The gel shown at the right is an ethidium bromide-stained 1\% agarose gel showing kDNA decatenation in the absence of enzyme (DNA), by human topoisomerase II $\alpha$ (hTII $\alpha$ ), by CVM-1 topoisomerase II (CVM), and by CVM-1 topoisomerase II in the absence of ATP (-ATP). Reaction mixtures contained $4 \mathrm{nM}$ enzyme. The positions of the kDNA networks at the origin, as well as those of the released DNA maxicircles and minicircles, are indicated.

\section{DNA Cleavage Activity of CVM-1 Topoisomerase II.}

A distinguishing characteristic of PBCV-1 topoisomerase II is its extraordinarily high DNA cleavage activity. To determine whether this remarkable feature extends to a distantly related chlorella virus, the ability of CVM-1 topoisomerase II to cleave DNA was optimized (Supporting Information Figure S2) and characterized. The CVM-1 enzyme displayed a robust DNA scission activity that was dramatically higher than that observed for human topoisomerase II $\alpha$ (Figure 4). At least 10-fold more plasmid was cleaved by the viral enzyme than was cleaved by an order of magnitude more human topoisomerase II $\alpha$. 


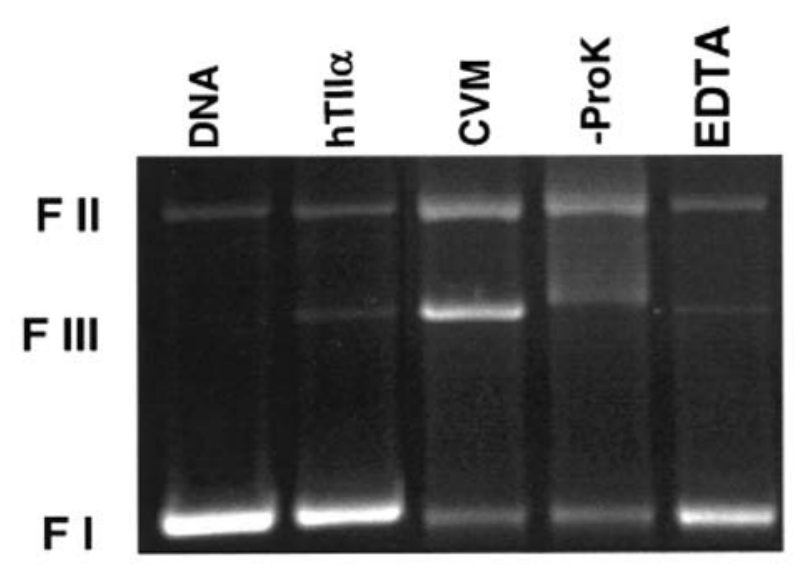

Figure 4: CVM-1 topoisomerase II displays a robust DNA cleavage activity that is protein-linked and reversible. The ethidium bromide-stained agarose gel shows a $10 \mathrm{nM}$ negatively supercoiled plasmid DNA control (DNA) and a DNA cleavage reaction carried out in the presence of $200 \mathrm{nM}$ human topoisomerase II $\alpha$ (hTII $\alpha$ ) or $20 \mathrm{nM}$ CVM-1 topoisomerase II (CVM-1). To determine whether the DNA cleaved by CVM-1 topoisomerase II was protein-linked, proteinase K treatment was omitted (-ProK). Reversibility of the cleavage reaction was determined by adding EDTA to the reaction prior to SDS treatment (EDTA). Double-stranded DNA cleavage converts negatively supercoiled plasmid (form I, FI) to linear molecules (form III, FIII). The position of nicked circular DNA (form II, FII) also is indicated. Data are representative of three independent experiments.

CVM-1 topoisomerase II was covalently attached to cleaved DNA molecules (Figure 4), as demonstrated by the decreased electrophoretic mobility of linearized plasmids when proteinase K treatment was omitted. ${ }^{2}$ Removal of the required $\mathrm{Mg}$ (II) by the addition of EDTA reversed DNA cleavage, converting linear plasmids back to negatively supercoiled molecules (Figure 4). This finding demonstrates that CVM-1 topoisomerase II remains active following DNA cleavage and that the high levels of scission are not due to the formation of a dead-end cleavage complex.

2. The electrophoretic shift of the linearized plasmid DNA observed in the absence of proteinase $\mathrm{K}$ was considerably less pronounced than previously seen for DNA cleaved by other type II enzymes. The DNA cleavage complex generally is shifted to the gel origin due to the strong interaction of topoisomerase II with the gel matrix. As determined by Coomassie staining of the gel, CVM-1 topoisomerase II co-localized with the linearized plasmid molecules (data not shown). This finding confirms that the viral enzyme is covalently attached to the cleaved DNA. At the present time, it is not known why CVM-1 topoisomerase II displays little affinity for agarose gel as compared to other type II enzymes. 


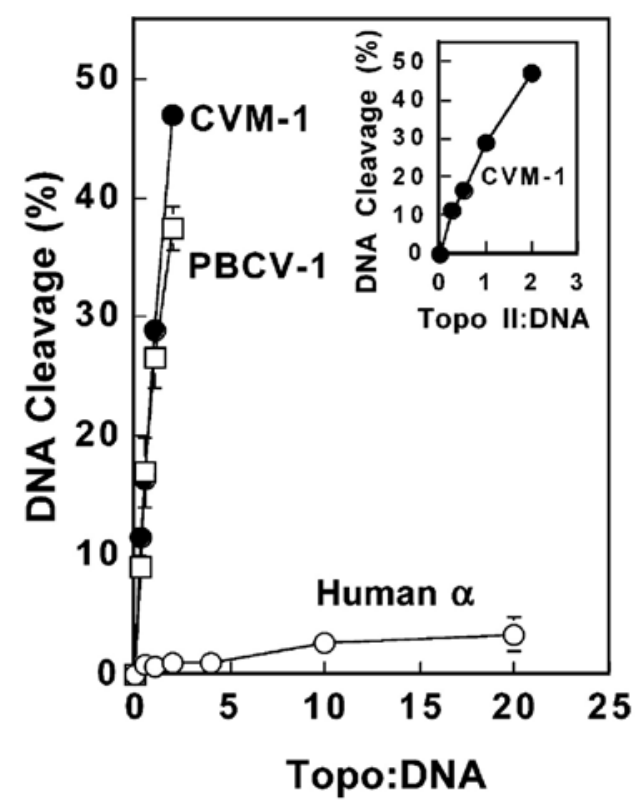

Figure 5: DNA cleavage by type II topoisomerases. The ability of CVM-1 topoisomerase II (closed circles), PBCV-1 topoisomerase II (open squares), and human topoisomerase II $\alpha$ (open circles) to cleave negatively supercoiled pBR322 plasmid DNA was determined. A range of enzyme:DNA ratios was examined at a constant concentration of $10 \mathrm{nM}$ plasmid. DNA cleavage mediated by CVM-1 topoisomerase II also is shown in the inset. Cleavage is expressed as the percentage of circular DNA substrate converted to linear molecules at equilibrium. Error bars represent the standard deviation of three independent experiments.

To further characterize the DNA scission activity of CVM-1 topoisomerase II, cleavage was quantified over a range of enzyme concentrations and compared to that of human topoisomerase II $\alpha$ and PBCV-1 topoisomerase II (Figure 5). At an enzyme:plasmid ratio of 2:1, CVM-1 topoisomerase II cleaved approximately half of the DNA molecules. This stands in marked contrast to human topoisomerase II $\alpha$, which cleaved less than $5 \%$ of the plasmid substrate at a enzyme:plasmid ratio of 20:1. The DNA scission activity of CVM-1 topoisomerase II was comparable to or slightly higher than that of the PBCV-1 enzyme. Taken together, these results demonstrate that CVM-1 topoisomerase II has an intrinsic DNA cleavage activity that is extremely high and is at least 50 times greater than that of human topoisomerase II $\alpha$. 
Site-Specific DNA Cleavage by CVM-1 Topoisomerase II.

DNA cleavage was monitored at the site-specific level by utilizing a singly end labeled linear plasmid substrate. Type II enzymes, including human topoisomerase II $\alpha$, typically cut DNA at a limited number of prominent sites (Figure 6, left). Anticancer drugs such as etoposide often enhance

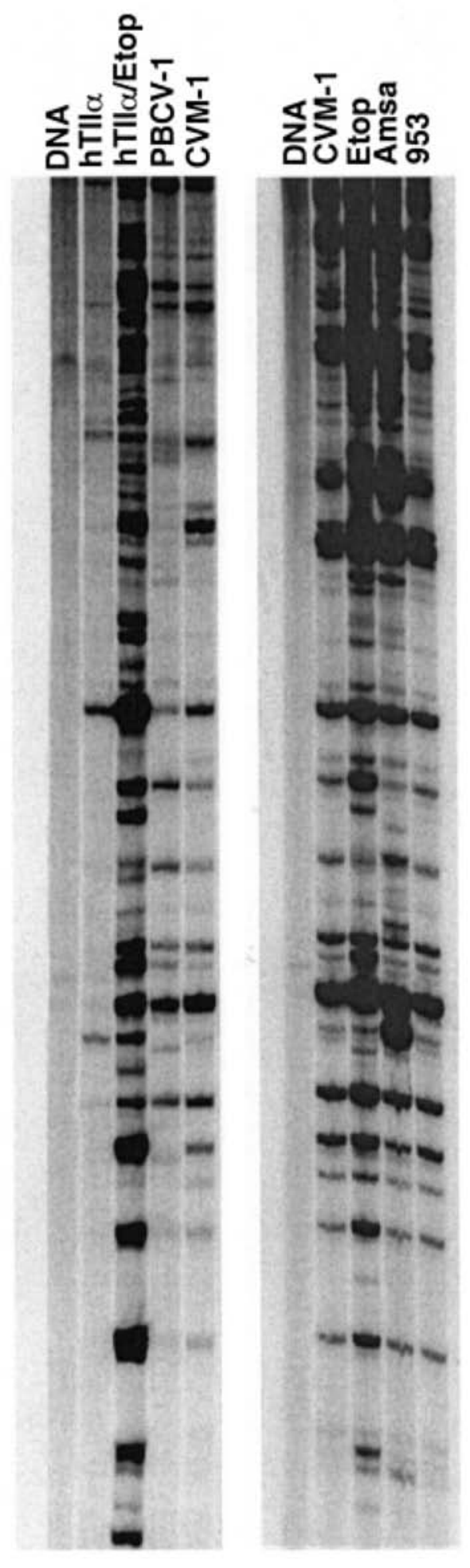

Figure 6: Distribution of topoisomerase II-mediated DNA cleavage sites on a linear DNA substrate. A singly end labeled 4330 bp fragment of pBR322 (1.5 nM) was employed. The autoradiogram at the left shows a DNA control (DNA) and cleavage in the presence of $60 \mathrm{nM}$ human topoisomerase II $\alpha$ (hTII $\alpha$ ), $60 \mathrm{nM}$ human topoisomerase II $\alpha$ plus $50 \mu \mathrm{M}$ etoposide (hTII $\alpha /$ Etop), 60 nM PBCV-1 topoisomerase II (PBCV1), or 60 nM CVM-1 topoisomerase II (CVM-1). The autoradiogram at the right shows a DNA control (DNA) and cleavage in the presence of 60 nM CVM-1 topoisomerase II with no drug (CVM-1) or enzyme plus $50 \mu \mathrm{M}$ etoposide (Etop), amsacrine (Amsa), or CP-115, 953 (953). Data are representative of three independent experiments. 
DNA scission at these same sites. However, the pronounced rise in strand breaks induced by these agents more often results from a dramatic increase in the number of sites cut by the enzyme. For example, inclusion of $50 \mu \mathrm{M}$ etoposide in cleavage assays converts topoisomerase II $\alpha$ from an enzyme that cuts DNA at a limited array of sites to one that cleaves at a far greater number of sequences.

As a first step toward understanding the basis for the robust DNA cleavage activity of CVM-1 topoisomerase, sites of DNA scission were mapped. Several aspects of CVM-1 topoisomerase II-mediated DNA cleavage were striking (Figure 6, left). First, the viral enzyme cut DNA at a modest number of sites and did not display the promiscuity associated with drug-enhanced DNA scission. Second, virtually every site cleaved by CVM-1 topoisomerase II had a counterpart (although usually considerably weaker) that was cleaved by human topoisomerase II $\alpha$. Third, despite the fact that CVM-1 and PBCV-1 topoisomerase II cut DNA at high levels and with a similar sequence specificity, differences in site utilization were observed.

Susceptibility of CVM-1 Topoisomerase II to Anticancer Drugs.

Of the known eukaryotic-like type II topoisomerases, the only enzyme that does not display a high susceptibility to anticancer agents is PBCV-1 topoisomerase II (45). Therefore, the effects of anticancer agents on the DNA cleavage activity of CVM-1 topoisomerase II were assessed. Three structurally and mechanistically diverse compounds were employed, etoposide, amsacrine, and the quinolone CP- 115,953 (10, 23, 69-73). Whereas etoposide and CP-115,953 bind DNA poorly (if at all), amsacrine is a strong DNA intercalator. Furthermore, while etoposide and amsacrine increase levels of DNA scission primarily by inhibiting the ability of topoisomerase II to ligate cleaved molecules, CP- 115,953 appears to act primarily by enhancing the forward rate of scission.

Drugs had relatively little effect on global cleavage of supercoiled plasmid molecules by CVM-1 topoisomerase II (data not shown). Using the more sensitive site-specific assay, etoposide and amsacrine enhanced cleavage at a limited number of sites (Figure 6, right). In contrast, no increase in cleavage was observed at any site in reactions that contained CP-115,953 (Figure 6, right). These results suggest that low sensitivity to DNA cleavage-enhancing anticancer drugs is a characteristic feature of type II topoisomerases from chlorella viruses. 


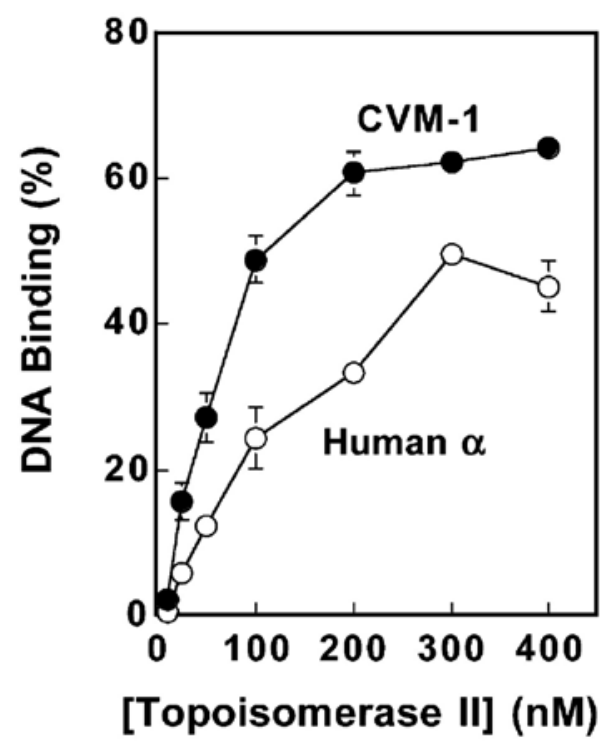

Figure 7: Topoisomerase II-DNA binding. The percent binding of radiolabeled linear pBR322 DNA to CVM-1 topoisomerase II (closed circles) or human topoisomerase II $\alpha$ (open circles) was determined by the ratio of cpm retained on a nitrocellulose filter vs the input amount of radioactivity. Error bars represent the standard deviation of three independent experiments.

\section{Binding of DNA to CVM-1 Topoisomerase II.}

Several factors may contribute to the robust DNA cleavage activity of CVM-1 topoisomerase II. Levels of DNA cleavage can be raised by increased DNA binding, enhanced rates of DNA scission, or diminished rates of DNA religation.

To determine whether the high levels of DNA cleavage mediated by the viral enzyme are related to a greater affinity for DNA, the ability of CVM-1 topoisomerase II to bind linear DNA molecules was determined. As seen in Figure 7, the affinity of the viral enzyme for DNA appeared to be slightly higher $(<2$-fold) than that of human topoisomerase II $\alpha$. This minor increase in DNA binding, however, cannot account for the dramatic difference in the level of DNA cleavage mediated by these two enzymes.

\section{Religation of Cleaved DNA by CVM-1 Topoisomerase II.}

At the present time, no assays are available that directly measure the forward rate of topoisomerase II-mediated DNA cleavage. However, a number of topoisomerase II-targeted anticancer drugs increase 


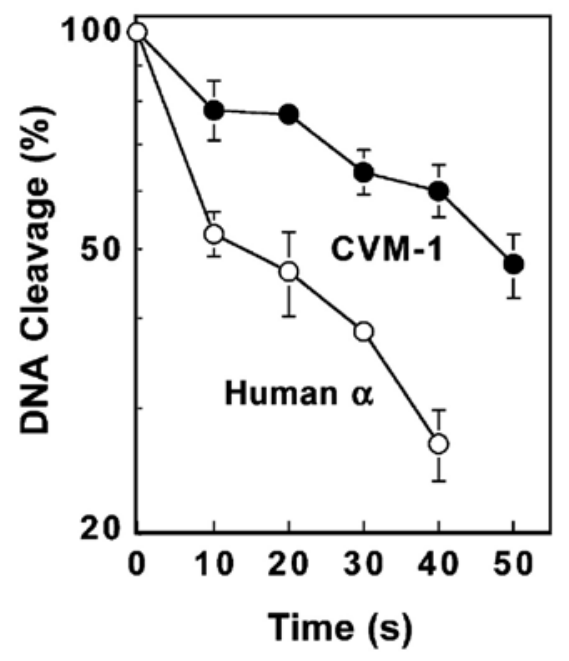

Figure 8: DNA religation mediated by CVM-1 topoisomerase II (closed circles) or human topoisomerase II $\alpha$ (open circles). The DNA cleavage/religation equilibrium was established as described for plasmid DNA cleavage reactions, and religation was initiated by shifting samples to $-5^{\circ} \mathrm{C}$. The DNA cleavage observed at equilibrium for each enzyme was set to $100 \%$ at time zero. Error bars represent the standard deviation of three independent experiments.

enzyme-generated DNA breaks by inhibiting the ability of topoisomerase II to religate cleaved DNA molecules $(10,23,69,74)$. Therefore, the rate of DNA religation mediated by CVM-1 topoisomerase II was determined (Figure 8). On the basis of the $t_{1 / 2}$ for religation, the apparent firstorder rate constant for DNA religation mediated by CVM-1 topoisomerase II was $\sim 3$-fold slower than that of human topoisomerase II $\alpha$. Once again, it does not appear that this difference can account for the $\sim 50$ fold greater DNA cleavage observed for CVM-1 topoisomerase II. While differences in the ability of the viral enzyme to bind and religate DNA appear to contribute to the high levels of DNA scission, the above results suggest that the robust DNA cleavage activity of CVM-1 topoisomerase II is caused primarily by a greater rate of DNA scission.

\section{Discussion}

Recently, the first type II topoisomerase was isolated from a virus that infects eukaryotic cells (44). In most respects, PBCV-1 topoisomerase II is similar to its eukaryotic counterparts. However, the viral enzyme 
displays a remarkably high DNA cleavage activity, 30-fold greater than that of previously characterized type II topoisomerases $(45,46)$. This unexpected finding significantly impacts the dogma that type II enzymes inherently maintain low levels of cleavage complexes, and led us to ask whether high DNA scission is unique to the PBCV-1 enzyme or is a conserved feature of chlorella viruses. Therefore, topoisomerase II from CVM-1, a chlorella virus that is distantly related to PBCV-1, was isolated and characterized (52).

CVM-1 topoisomerase II is 1058 amino acids in length (3 amino acids shorter than the PBCV-1 enzyme), making it the smallest known type II topoisomerase. The enzyme displays a vigorous double-stranded DNA strand passage activity and cleaves DNA at levels that exceed those of PBCV-1 topoisomerase II. High DNA cleavage does not result from an inordinately tight binding between the viral enzyme and DNA or a diminished ability to religate cleaved strands. Rather, it is suggested that high cleavage is caused primarily by an increase in the forward rate of DNA scission. These findings are consistent with the high overall catalytic activity of CVM-1 topoisomerase II. On the basis of the above, we conclude that robust DNA cleavage is a fundamental property of type II enzymes from chlorella viruses.

Of the known viral families that infect eukaryotic hosts, members of only four encode a topoisomerase of any kind (75). Three of the four, including Phycodnaviridae (which contains the chlorella viruses) $(49,51$, 76), Asfarviridae (which contains African swine fever virus) $(77,78)$, and Iridoviridae (which contains Chilo iridescent virus) (79), have open reading frames that are homologous to eukaryotic type II topoisomerases (75). Like chlorella virus topoisomerase II, the predicted type II enzymes from African swine fever virus and Chilo iridescent virus (1191 and 1132 amino acids in length, respectively) are much smaller than eukaryotic topoisomerase II (77-79). The fourth virus family, Poxviridae (which contains vaccinia virus), encodes a type IB topoisomerase (65, 80-82). Vaccinia topoisomerase is by far the smallest known type I enzyme (314 amino acids) and possesses a DNA cleavage activity that is both greater and considerably more site-specific than those of any other characterized type IB topoisomerase $(65,82-84)$.

It is notable that these four viral families are believed to be "monophyletic," in the sense that they are evolutionarily related to the exclusion of all other viruses (75). These families all have large double-stranded DNA genomes that are characterized by hairpin telomeres or circularly 
permuted ends (85-89). In addition, they encode many of the proteins required for viral replication, and replicate in part or entirely in the host cytoplasm $(49,51,76,87,88,90,91)$.

It is not known why these viruses encode their own topoisomerases. However, the high DNA cleavage activity of the chlorella virus type II and poxvirus type I topoisomerases suggest that these enzymes play a role in the viral life cycle that extends beyond the control of DNA topology. For example, it has been proposed that vaccinia virus topoisomerase is involved in resolving hairpin telomeres during replication (92). In addition, these enzymes may play a role in initiating viral DNA recombination or in fragmenting the host genome. Alternatively, the high DNA cleavage activity of chlorella virus topoisomerase II may reflect some unique aspect of the viral environment, such as the high DNA methylation of the CVM-1 genome.

Finally, the high amino acid sequence identity and other properties shared by chlorella virus and eukaryotic topoisomerase II make CVM-1 and PBCV-1 topoisomerase II ideal models for studying the DNA cleavage reaction of type II enzymes. Although topoisomerase II-mediated DNA scission and ligation play important roles in upholding genomic stability, the low DNA cleavage activity of eukaryotic type II enzymes has made it impossible to address many questions regarding these critical reactions (24). The extraordinarily high steady-state concentration of cleavage complexes maintained by chlorella virus topoisomerase II provides a unique tool to address these vital issues.

Acknowledgments - We are grateful to Mike Graves for sequencing part of the CVM-1 genome, to Tony Fehr for help with the initial cloning of the CVM-1 topoisomerase II gene, and to Erin L. Baldwin and Renier Vélez-Cruz for critical reading of the manuscript.

\section{Supporting Information}

Supporting information details the procedure used to isolate recombinant CVM-1 topoisomerase II. A silver-stained SDS-polyacrylamide gel containing purified recombinant CVM-1 topoisomerase II, PBCV-1 topoisomerase II, and human topoisomerase II $\alpha$ is included in the supporting information as Figure S1 to demonstrate purity of the sample. Also, optimization of the $\mathrm{MgCl} 2$ concentration, temperature, $\mathrm{pH}$, and $\mathrm{KCl}$ concentration for DNA cleavage mediated by CVM-1 topoisomerase II is shown in Figure S2. This material follows the References. 


\section{References}

1. Wang, J. C. (1996) DNA topoisomerases, Annu. Rev. Biochem. 65, 635-692.

2. Cozzarelli, N. R., and Wang, J. C. (1990), DNA Topology and Its Biological Effects, Cold Spring Harbor Laboratory Press, Cold Spring Harbor, NY.

3. Nitiss, J. L. (1994) Roles of DNA topoisomerases in chromosomal replication and segregation, Adv. Pharmacol. 29A, 103-134.

4. Nitiss, J. L. (1998) Investigating the biological functions of DNA topoisomerases in eukaryotic cells, Biochim. Biophys. Acta 1400, 63-81.

5. Peter, B. J., Ullsperger, C., Hiasa, H., Marians, K. J., and Cozzarelli, N. R. (1998) The structure of supercoiled intermediates in DNA replication, Cell 94, 819-827.

6. DiNardo, S., Voelkel, K., and Sternglanz, R. (1984) DNA topoisomerase II mutant of Saccharomyces cerevisiae: topoisomerase II is required for segregation of daughter molecules at the termination of DNA replication, Proc. Natl. Acad. Sci. U.S.A. 81, 2616-2620.

7. Wang, J. C. (2002) Cellular roles of DNA topoisomerases: a molecular perspective, Nat. Rev. Mol. Cell Biol. 3, 430-440.

8. Levine, C., Hiasa, H., and Marians, K. J. (1998) DNA gyrase and topoisomerase IV: biochemical activities, physiological roles during chromosome replication, and drug sensitivities, Biochim. Biophys. Acta 1400, 29-43.

9. Pommier, Y., Pourquier, P., Fan, Y., and Strumberg, D. (1998) Mechanism of action of eukaryotic DNA topoisomerase I and drugs targeted to the enzyme, Biochim. Biophys. Acta 1400, 83- 106.

10. Burden, D. A., and Osheroff, N. (1998) Mechanism of action of eukaryotic topoisomerase II and drugs targeted to the enzyme, Biochim. Biophys. Acta 1400, 139-154.

11. Wyckoff, E., Natalie, D., Nolan, J. M., Lee, M., and Hsieh, T. (1989) Structure of the Drosophila DNA topoisomerase II gene. Nucleotide sequence and homology among topoisomerases II, J. Mol. Biol. 205, 1-13.

12. Goto, T., and Wang, J. C. (1984) Yeast DNA topoisomerase II is encoded by a single-copy, essential gene, Cell 36, 1073-1080.

13. Drake, F. H., Zimmerman, J. P., McCabe, F. L., Bartus, H. F., Per, S. R., Sullivan, D. M., Ross, W. E., Mattern, M. R., Johnson, R. K., and Crooke, S. T. (1987) Purification of topoisomerase II from amsacrine-resistant P388 leukemia cells. Evidence for two forms of the enzyme, J. Biol. Chem. 262, 16739-16747.

14. Drake, F. H., Hofmann, G. A., Bartus, H. F., Mattern, M. R., Crooke, S. T., and Mirabelli, C. K. (1989) Biochemical and pharmacological properties of p170 and p180 forms of topoisomerase II, Biochemistry 28, 8154-8160.

15. Woessner, R. D., Mattern, M. R., Mirabelli, C. K., Johnson, R. K., and Drake, F. H. (1991) Proliferation- and cell cycle-dependent differences in expression of the 170 kilodalton and 180 kilodalton forms of topoisomerase II in NIH-3T3 cells, Cell Growth Differ. 2, 209-214.

16. Heck, M. M., and Earnshaw, W. C. (1986) Topoisomerase II: A specific marker for cell proliferation, J. Cell Biol. 103, 2569- 2581. 
17. Sullivan, D. M., Latham, M. D., and Ross, W. E. (1987) Proliferation-dependent topoisomerase II content as a determinant of antineoplastic drug action in human, mouse, and Chinese hamster ovary cells, Cancer Res. 47, 3973-3979.

18. Hsiang, Y. H., Wu, H. Y., and Liu, L. F. (1988) Proliferation-dependent regulation of DNA topoisomerase II in cultured human cells, Cancer Res. 48, 3230-3235.

19. Bauman, M. E., Holden, J. A., Brown, K. A., Harker, W. G., and Perkins, S. L. (1997) Differential immunohistochemical staining for DNA topoisomerase II $\alpha$ and $\beta$ in human tissues and for DNA topoisomerase II $\beta$ in non-Hodgkin's lymphomas, Mod. Pathol. 10, 168-175.

20. Austin, C. A., and Marsh, K. L. (1998) Eukaryotic DNA topoisomerase II $\beta$, BioEssays 20, 215-226.

21. Isaacs, R. J., Davies, S. L., Sandri, M. I., Redwood, C., Wells, N. J., and Hickson, I. D. (1998) Physiological regulation of eukaryotic topoisomerase II, Biochim. Biophys. Acta 1400, 121-137.

22. Berger, J. M., Gamblin, S. J., Harrison, S. C., and Wang, J. C. (1996) Structure and mechanism of DNA topoisomerase II, Nature 379, 225-232.

23. Fortune, J. M., and Osheroff, N. (2000) Topoisomerase II as a target for anticancer drugs: when enzymes stop being nice, Prog. Nucleic Acid Res. Mol. Biol. 64, 221-253.

24. Wilstermann, A. M., and Osheroff, N. (2003) Stabilization of eukaryotic topoisomerase II-DNA cleavage complexes, Curr. Top. Med. Chem. 3, 321-338.

25. Kaufmann, S. H. (1998) Cell death induced by topoisomerase-targeted drugs: more questions than answers, Biochim. Biophys. Acta 1400, 195-211.

26. Felix, C. A. (1998) Secondary leukemias induced by topoisomerase- targeted drugs, Biochim. Biophys. Acta 1400, 233-255.

27. Rowley, J. D. (1998) The critical role of chromosome translocations in human leukemias, Annu. Rev. Genet. 32, 495-519.

28. Kaufmann, S. H., Gore, S. D., Miller, C. B., Jones, R. J., Zwelling, L. A., Schneider, E., Burke, P. J., and Karp, J. E. (1998) Topoisomerase II and the response to antileukemic therapy, Leuk. Lymphoma 29, 217-237.

29. Sordet, O., Khan, Q. A., Kohn, K. W., and Pommier, Y. (2003) Apoptosis induced by topoisomerase inhibitors, Curr. Med. Chem. Anti-Cancer Agents 3, 271-290.

30. Smith, M. T., Wang, Y., Skibola, C. F., Slater, D. J., Lo Nigro, L., Nowell, P. C., Lange, B. J., and Felix, C. A. (2002) Low NAD(P)H:quinone oxidoreductase activity is associated with increased risk of leukemia with MLL translocations in infants and children, Blood 100, 4590-4593.

31. Hutt, A. M., and Kalf, G. F. (1996) Inhibition of human DNA topoisomerase II by hydroquinone and p-benzoquinone, reactive metabolites of benzene, Environ. Health Perspect. 104 (Suppl. 6), 1265-1269.

32. Baker, R. K., Kurz, E. U., Pyatt, D. W., Irons, R. D., and Kroll, D. J. (2001) Benzene metabolites antagonize etoposide-stabilized cleavable complexes of DNA topoisomerase IIalpha, Blood 98, 830-833.

33. Chen, H., and Eastmond, D. A. (1995) Topoisomerase inhibition by phenolic metabolites: a potential mechanism for benzene's clastogenic effects, Carcinogenesis 16, 2301-2307. 
34. DeVore, R., Whitlock, J., Hainsworth, T., and Johnson, D. (1989) Therapy-related acute nonlymphocytic leukemia with monocytic features and rearrangement of chromosome 11q., Ann. Intern. Med. 110, 740-742.

35. Ratain, M. J., and Rowley, J. D. (1992) Therapy-related acute myeloid leukemia secondary to inhibitors of topoisomerase II: from the bedside to the target genes., Ann. Oncol. 3, 107-111.

36. Felix, C. A., and Lange, B. J. (1999) Leukemia in infants, Oncologist 4, 225-240.

37. Strick, R., Strissel, P. L., Borgers, S., Smith, S. L., and Rowley, J. D. (2000) Dietary bioflavonoids induce cleavage in the MLL gene and may contribute to infant leukemia, Proc. Natl. Acad. Sci. U.S.A., 1-6 (early edition).

38. Felix, C. A. (2001) Leukemias related to treatment with DNA topoisomerase II inhibitors, Med. Pediatr. Oncol. 36, 525-535.

39. Smith, M. A., Rubinstein, L., Anderson, J. R., Arthur, D., Catalano, P. J., Freidlin, B., Heyn, R., Khayat, A., Krailo, M., Land, V. J., Miser, J., Shuster, J., and Vena, D. (1999) Secondary leukemia or myelodysplastic syndrome after treatment with epipodophyllotoxins, J. Clin. Oncol. 17, 569-577.

40. Ross, J. A., Potter, J. D., and Robison, L. L. (1994) Infant leukemia, topoisomerase II inhibitors, and the MLL gene., J. Natl. Cancer Inst. 86, 1678-1680.

41. Ross, J. A., Potter, J. D., Reaman, G. H., Pendergrass, T. W., and Robison, L. L. (1996) Maternal exposure to potential inhibitors of DNA topoisomerase II and infant leukemia (United States): a report from the Children's Cancer Group, Cancer Causes Control 7, 581-590.

42. Lindsey, R. H., Jr., Bromberg, K. D., Felix, C. A., and Osheroff, N. (2004) 1,4-Benzoquinone is a topoisomerase II poison, Biochemistry 43, 7563-7574.

43. Bender, R. P., Lindsey, R. H., Jr., Burden, D. A., and Osheroff, N. (2004) N-acetyl-pbenzoquinone imine, the toxic metabolite of acetaminophen, is a topoisomerase II poison, Biochemistry 43, 3731-3739.

44. Lavrukhin, O. V., Fortune, J. M., Wood, T. G., Burbank, D. E., Van Etten, J. L., Osheroff, N., and Lloyd, R. S. (2000) Topoisomerase II from Chlorella virus PBCV1. Characterization of the smallest known type II topoisomerase, J. Biol. Chem. 275, 6915-6921.

45. Fortune, J. M., Lavrukhin, O. V., Gurnon, J. R., Van Etten, J. L., Lloyd, R. S., and Osheroff, N. (2001) Topoisomerase II from Chlorella virus PBCV-1 has an exceptionally high DNA cleavage activity, J. Biol. Chem. 276, 24401-24408.

46. Fortune, J. M., Dickey, J. S., Lavrukhin, O. V., Van Etten, J. L., Lloyd, R. S., and Osheroff, N. (2002) Site-specific DNA cleavage by Chlorella virus topoisomerase II, Biochemistry 41, 11761- 11769.

47. Li, Y., Lu, Z., Sun, L., Ropp, S., Kutish, G. F., Rock, D. L., and Van Etten, J. L. (1997) Analysis of $74 \mathrm{~kb}$ of DNA located at the right end of the $330-\mathrm{kb}$ Chlorella virus PBCV-1 genome, Virology 237, 360-377.

48. Van Etten, J. L., Lane, L. C., and Meints, R. H. (1991) Viruses and virus-like particles of eukaryotic algae, Microbiol. Rev. 55, 586-620.

49. Van Etten, J. L., and Meints, R. H. (1999) Giant viruses infecting algae, Annu. Rev. Microbiol. 53, 447-494. 
50. Van Etten, J. L. (2000) in Virus Taxonomy, Classification and Nomenclature of Viruses, Seventh Report (Van Regenmortel, M. H. V., Fauquet, C. M., Bishop, D. H. L., Carsten, E. B., Estes, M. K., Lemon, S. M., Maniloff, J., Mayo, M. A., McGeoch, D. J., Pringle, C. R., and Wickner, R. B., Eds.) pp 183-193, Academic Press, San Diego.

51. Van Etten, J. L. (2003) Unusual life style of giant chlorella viruses, Annu. Rev. Genet. 37, 153-195.

52. Reisser, W., Burbank, D. E., Meints, S. M., Meints, R. H., Becker, B., and Van Etten, J. L. (1988) A comparison of viruses infecting two different Chlorella-like green algae, Virology 167, 143-149.

53. Englund, P. T. (1978) The replication of kinetoplast DNA networks in Crithidia fasciculata, Cell 14, 157-168.

54. Kingma, P. S., Greider, C. A., and Osheroff, N. (1997) Spontaneous DNA lesions poison human topoisomerase II $\alpha$ and stimulate cleavage proximal to leukemic 11q23 chromosomal breakpoints, Biochemistry 36, 5934-5939.

55. Fortune, J. M., and Osheroff, N. (1998) Merbarone inhibits the catalytic activity of human topoisomerase II $\alpha$ by blocking DNA cleavage, J. Biol. Chem. 273, 17643-17650.

56. Miller, K. G., Liu, L. F., and Englund, P. T. (1981) A homogeneous type II DNA topoisomerase from HeLa cell nuclei, J. Biol. Chem. 256, 9334-9339.

57. O’Reilly, E. K., and Kreuzer, K. N. (2002) A unique type II topoisomerase mutant that is hypersensitive to a broad range of cleavage-inducing antitumor agents, Biochemistry 41, 7989-7997.

58. Robinson, M. J., and Osheroff, N. (1990) Stabilization of the topoisomerase II-DNA cleavage complex by antineoplastic drugs: inhibition of enzyme-mediated DNA religation by 4'-(9-acridinylamino)methanesulfon-m-anisidide, Biochemistry 29, 2511- 2515.

59. Nelson, M., Burbank, D. E., and Van Etten, J. L. (1998) Chlorella viruses encode multiple DNA methyltransferases, Biol. Chem. 379, 423-428.

60. Tse-Dinh, Y. C. (1998) Bacterial and archeal type I topoisomerases, Biochim. Biophys. Acta 1400, 19-27.

61. Champoux, J. J. (1994) Mechanism of catalysis by eukaryotic DNA topoisomerase I., Adv. Pharmacol. 29, 71-82.

62. Champoux, J. J. (1998) Domains of human topoisomerase I and associated functions, Prog. Nucleic Acid Res. Mol. Biol. 60, 111- 132.

63. Redinbo, M. R., Stewart, L., Kuhn, P., Champoux, J. J., and Hol, W. G. J. (1998) Crystal structures of human topoisomerase I in covalent and noncovalent complexes with DNA, Science 279, 1504-1513.

64. Stewart, L., Redinbo, M. R., Qiu, X., Hol, W. G. J., and Champoux, J. J. (1998) A model for the mechanism of human topoisomerase I, Science 279, 1534-1541.

65. Shuman, S. (1998) Vaccinia virus DNA topoisomerase: a model eukaryotic type IB enzyme, Biochim. Biophys. Acta 1400, 321- 337.

66. Champoux, J. J. (2001) DNA TOPOISOMERASES: Structure, Function, and Mechanism, Annu. Rev. Biochem. 70, 369-413. 
67. Watt, P. M., and Hickson, I. D. (1994) Structure and function of type II DNA topoisomerases, Biochem. J. 303, 681-695.

68. Wang, J. C. (1998) Moving one DNA double helix through another by a type II DNA topoisomerase: the story of a simple molecular machine, Q. Rev. Biophys. 31, 107-144.

69. Corbett, A. H., and Osheroff, N. (1993) When good enzymes go bad: conversion of topoisomerase II to a cellular toxin by antineoplastic drugs, Chem. Res. Toxicol. 6, 585-597.

70. Macdonald, T. L., Legnert, E. K., Loper, J. T., Chow, K.-C., and Ross, W. E. (1991) in DNA Topoisomerases in Cancer (Potmesil, M., and Kohn, K. W., Eds.) pp 199-214, Oxford University Press, New York.

71. Pommier, Y. (1997) in Cancer Therapeutics: Experimental and Clinical Agents (Teicher, B. A., Ed.) pp 153-174, Humana Press, Totowa, NJ.

72. Hande, K. R. (1998) Clinical applications of anticancer drugs targeted to topoisomerase II, Biochim. Biophys. Acta 1400, 173- 184.

73. Li, T. K., and Liu, L. F. (2001) Tumor cell death induced by topoisomerasetargeting drugs, Annu. Rev. Pharmacol. Toxicol. 41, 53-77.

74. Osheroff, N., Corbett, A. H., and Robinson, M. J. (1994) in Advances in Pharmacology (Liu, L., Ed.) pp 105-126, Academic Press, New York.

75. Iyer, L. M., Aravind, L., and Koonin, E. V. (2001) Common origin of four diverse families of large eukaryotic DNA viruses, J. Virol. 75, 11720-11734.

76. Van Etten, J. L., Graves, M. V., Muller, D. G., Boland, W., and Delaroque, N. (2002) Phycodnaviridae-large DNA algal viruses, Arch. Virol. 147, 1479-1516.

77. Baylis, S. A., Dixon, L. K., Vydelingum, S., and Smith, G. L. (1992) African swine fever virus encodes a gene with extensive homology to type II DNA topoisomerases, J. Mol. Biol. 228, 1003-1010.

78. Garcia-Beato, R., Freije, J. M., Lopez-Otin, C., Blasco, R., Vinuela, E., and Salas, M. L. (1992) A gene homologous to topoisomerase II in African swine fever virus, Virology 188, 938-947.

79. Muller, K., Tidona, C. A., and Darai, G. (1999) Identification of a gene cluster within the genome of Chilo iridescent virus encoding enzymes involved in viral DNA replication and processing, Virus Genes 18, 243-264.

80. Bauer, W. R., Ressner, E. C., Kates, J., and Patzke, J. V. (1977) A DNA nicking-closing enzyme encapsidated in vaccinia virus: partial purification and properties, Proc. Natl Acad. Sci. U.S.A. 74, 1841-1845.

81. Shaffer, R., and Traktman, P. (1987) Vaccinia virus encapsidates a novel topoisomerase with the properties of a eucaryotic type I enzyme, J. Biol. Chem. 262, 9309-9315.

82. Shuman, S., and Moss, B. (1987) Identification of a vaccinia virus gene encoding a type I DNA topoisomerase, Proc. Natl. Acad. Sci. U.S.A. 84, 7478-7482.

83. Shuman, S., and Prescott, J. (1990) Specific DNA cleavage and binding by vaccinia virus DNA topoisomerase I, J. Biol. Chem. 265, 17826-17836.

84. Shuman, S. (1991) Site-specific interaction of vaccinia virus topoisomerase I with duplex DNA. Minimal DNA substrate for strand cleavage in vitro, J. Biol. Chem.

266, 11372-11379. 
85. Traktman, P. (1990) The enzymology of poxvirus DNA replication, Curr. Top. Microbiol. Immunol. 163, 93-123.

86. Tidona, C. A., and Darai, G. (1997) Molecular anatomy of lymphocystis disease virus, Arch. Virol. (Suppl. 13), 49-56.

87. Vinuela, E. (1985) African swine fever virus, Curr. Top. Microbiol. Immunol. 116, 151-170.

88. Williams, T. (1996) The iridoviruses, Adv. Virus Res. 46, 345- 412.

89. Zhang, Y., Strasser, P., Grabherr, R., and Van Etten, J. L. (1994) Hairpin loop structure at the termini of the chlorella virus PBCV-1 genome, Virology 202, 1079-1082.

90. Garcia-Beato, R., Salas, M. L., Vinuela, E., and Salas, J. (1992) Role of the host cell nucleus in the replication of African swine fever virus DNA, Virology 188, 637-649.

91. McAuslan, B. R., and Armentrout, R. W. (1974) The biochemistry of icosahedral cytoplasmic deoxyviruses, Curr. Top. Microbiol. Immunol., 77-105.

92. DeLange, A. M., and McFadden, G. (1990) The role of telomeres in poxvirus DNA replication, Curr. Top. Microbiol. Immunol. 163, 71-92. 


\section{Supporting Information for}

\section{Chlorella Virus Marburg Topoisomerase II: High DNA Cleavage Activity as a Characteristic of Chlorella Virus Type II Enzymes ${ }^{\dagger}$}

Jennifer S. Dickey ${ }^{\ddagger}$, Tae-Jin Choil ${ }^{\|,\|}$, James L. Van Etten ${ }^{\|, \perp}$, Neil Osheroff ${ }^{\ddagger, \&, *}$

Departments of Biochemistry and Medicine (Hematology/Oncology), Vanderbilt University School of Medicine, Nashville, TN 37232-0146, and Department of Plant Pathology and Nebraska Center for Virology, University of Nebraska, Lincoln, NE 68583-0722 
Purification of CVM-1 Topoisomerase II. Enzyme purification was carried out by a modification of the protocol of Lavrukhin et al. (44). All steps were carried out at $4{ }^{\circ} \mathrm{C}$. Cells from 2-Liter yeast cultures were centrifuged for $10 \mathrm{~min}$ at $4,000 \mathrm{~g}$, resuspended in $35 \mathrm{~mL}$ of buffer A (15 mM sodium phosphate, $\mathrm{pH} 6.8,500 \mathrm{mM} \mathrm{NaCl}, 10 \%$ glycerol, $1 \mathrm{mM}$ EDTA, $1 \mathrm{mM}$ EGTA, $0.5 \mathrm{mM}$ DTT, $0.2 \mathrm{mM}$ PMSF, $1 \mu \mathrm{g} / \mathrm{mL}$ pepstatin, $1 \mu \mathrm{g} / \mathrm{mL}$ leupeptin), and disrupted by bead beating. Cell debris was removed by centrifugation at 20,000 $g$ for 10 min. Nucleic acids were precipitated by the slow addition of $5 \%(\mathrm{w} / \mathrm{v})$ polyethylenimine (Sigma) to the supernatant, with stirring to $0.1 \%$ final concentration. Stirring was continued for $30 \mathrm{~min}$ after all the polyethylenimine was added. The suspension was centrifuged at $20,000 \mathrm{~g}$ for $10 \mathrm{~min}$, the pellet was resuspended, and $\left(\mathrm{NH}_{4}\right)_{2} \mathrm{SO}_{4}$ was added slowly with stirring to the supernatant to $35 \%$ saturation. The suspension was stirred for an additional $30 \mathrm{~min}$ and precipitated proteins were removed by centrifugation at $20,000 \mathrm{~g}$ for $30 \mathrm{~min}$. $\left(\mathrm{NH}_{4}\right)_{2} \mathrm{SO}_{4}$ was added slowly to the supernatant to $65 \%$ saturation, and the suspension was stirred for $30 \mathrm{~min}$ and centrifuged as above. Precipitated proteins were resuspended in the volume of buffer B ( $25 \mathrm{mM}$ sodium phosphate, $\mathrm{pH}$ 6.8, $10 \%$ glycerol, $0.5 \mathrm{mM}$ DTT, $0.1 \mathrm{mM}$ PMSF, $1 \mu \mathrm{g} / \mathrm{mL}$ leupeptin, $1 \mu \mathrm{g} / \mathrm{mL}$ pepstatin) required to produce the equivalent of $0.2 \mathrm{M}$ residual $\left(\mathrm{NH}_{4}\right)_{2} \mathrm{SO}_{4}$.

Resuspended proteins were applied to a $20 \mathrm{~mL}$ hydroxylapatite column $(1.5 \mathrm{~cm}$ diameter $)$ that had been equilibrated with buffer $\mathrm{C}(15 \mathrm{mM}$ sodium phosphate, $\mathrm{pH} 6.8,200 \mathrm{mM}$ potassium phosphate, $\mathrm{pH}$ 6.8, $10 \%$ glycerol, $0.5 \mathrm{mM}$ DTT, $0.1 \mathrm{mM}$ PMSF, $1 \mu \mathrm{g} / \mathrm{mL}$ leupeptin, $1 \mu \mathrm{g} / \mathrm{mL}$ pepstatin). The column was washed with three volumes of buffer $\mathrm{C}$ and protein was eluted with a $100 \mathrm{~mL}$ linear salt gradient from 200 to $750 \mathrm{mM}$ potassium phosphate in buffer C. Fractions $(1.8 \mathrm{~mL})$ were collected and checked for the presence of a $120 \mathrm{kDa}$ protein band by SDSpolyacrylamide gel electrophoresis. Appropriate fractions were pooled, diluted with buffer D 
(15 mM sodium phosphate, $\mathrm{pH} 6.8,1 \mathrm{mM}$ EDTA, $1 \mathrm{mM}$ EGTA, $0.5 \mathrm{mM}$ DTT) to a final potassium phosphate concentration of $<200 \mathrm{mM}$, and applied to a phosphocellulose column (1 $\mathrm{mL}, 0.7 \mathrm{~cm}$ diameter) that had been equilibrated in buffer $\mathrm{D}$ that contained $200 \mathrm{mM} \mathrm{NaCl}$. CVM-1 topoisomerase II was eluted with buffer D that contained $750 \mathrm{mM} \mathrm{NaCl}$. Glycerol was added to a final concentration of $10 \%(w / v)$, and CVM-1 topoisomerase II was aliquoted and stored in liquid nitrogen. Protein concentrations throughout the purification were determined by absorbance at $595 \mathrm{~nm}$, using the Bio-Rad Bradford assay kit. For all assays requiring enzyme dilution, CVM-1 topoisomerase II was freshly diluted in buffer D containing $200 \mathrm{nM} \mathrm{NaCl}$ and $40 \%$ glycerol. 
FIGURE S1. CVM-1 topoisomerase II preparation. Samples $(1.5 \mu \mathrm{g})$ of purified recombinant CVM-1 topoisomerase II (CVM-1), PBCV-1 topoisomerase II (PBCV-1), and human topoisomerase II $\alpha(\mathrm{hTII} \alpha)$ were subjected to electrophoresis on a $7.5 \%$ denaturing SDSpolyacrylamide gel and visualized with silver stain. Arrows indicate the electrophoretic mobility of 200 and $120 \mathrm{kDa}$ molecular weight standards.

FIGURE S2. Optimization of DNA cleavage mediated by CVM-1 topoisomerase II. The effects of $\mathrm{Mg}(\mathrm{II})(\mathrm{A})$, temperature (B), $\mathrm{pH}(\mathrm{C})$, and salt (D) on the cleavage of plasmid DNA by CVM-1 topoisomerase II are shown. Cleavage is expressed as the percentage of circular DNA substrate converted to linear molecules at equilibrium. 


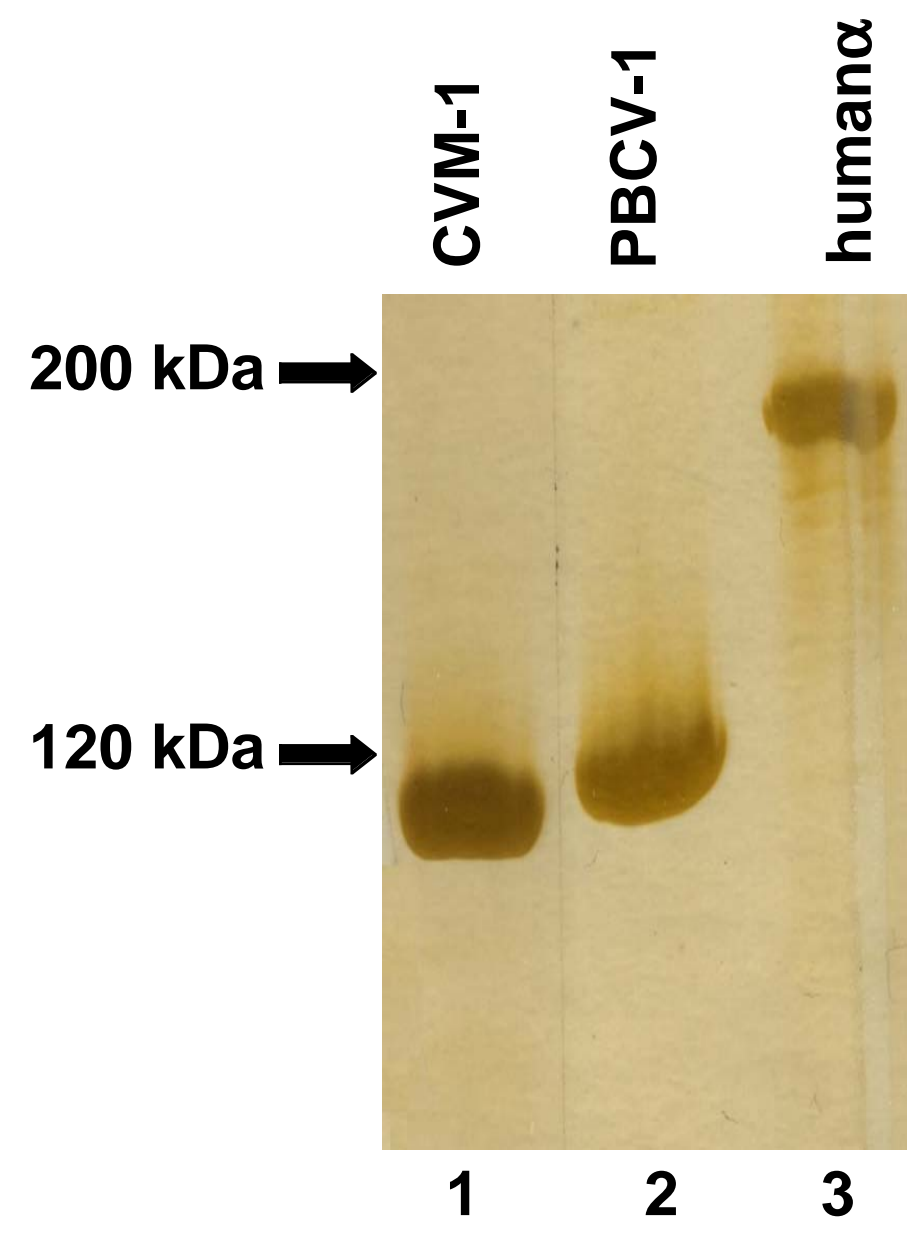



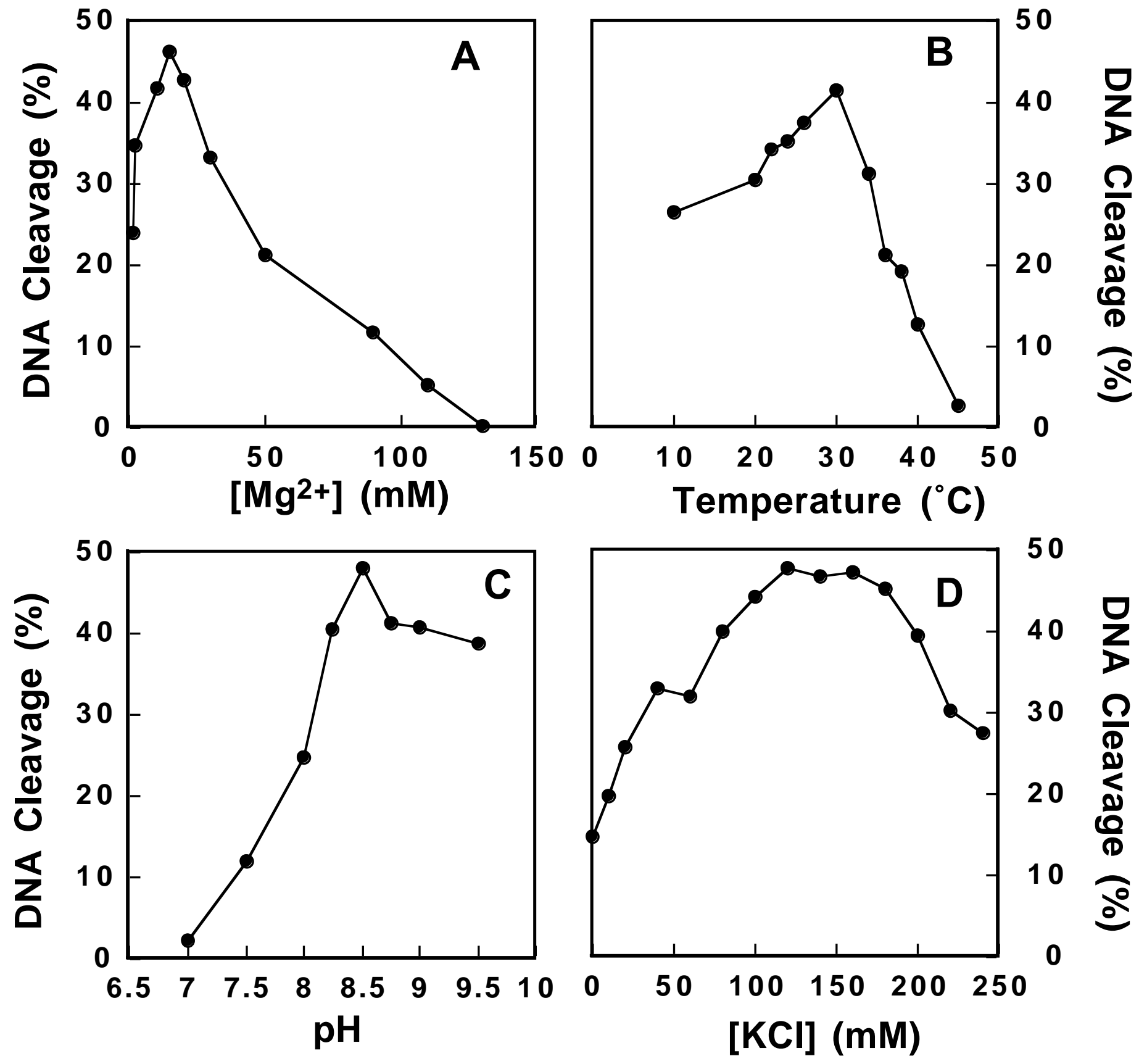

FIGURE S2 